https://doi.org/10.48009/1_iis_2010_224-231

\title{
CELLULAR TELEPHONES: A USEFUL TECHNOLOGY WITH DANGEROUS CONSEQUENCES
}

\author{
Robbie Connell, Texas A\&M University, robbie_78881@yahoo.com \\ Jack Shorter, Texas A\&M University, jack.shorter@tamuk.edu \\ Richard Aukerman, Texas A\&M University, kfraa00@tamuk.edu
}

\begin{abstract}
Mobile communication devices have evolved from a modern convenience to a necessity. While these handy gadgets do have many positive aspects, they have some very serious negative side effects. First, the implications of using a cell phone while driving will be discussed, followed by the controversial issue of cell phones emitting harmful electromagnetic fields and radio frequencies which (some researchers are starting to fear) cause brain tumors in the heads of regular cell phone users.
\end{abstract}

Keywords: Cell Phones, Mobile Phones, Mobile Phones \& Driving, Mobile Phones \& Health Hazards, Mobile Phones \& Cancer, Mobile Phones \& Brain Tumors

\section{INTRODUCTION}

Mobile communication devices have evolved from a modern convenience to a necessity. It is not often that a person in public does not see someone using their mobile device. Maples, DeRosier, Hoenes, Bendure, and Moore (2008) reported that more than $50 \%$ of United States citizens own cell phones, which is an international trend. [11] The entire world is capable of being connected 24hours a day and 7 days a week with this tool. The California Department of Motor Vehicles [2] came to the conclusion that cell phone use has become so popular that people don't realize when, where, or even how often they are utilizing their cellular telephones. Mobile devices have advanced in the past several years. Making and answering a phone call was the only reason for having a cell phone "back in the day", now users of these hand-held tools are constantly accessing them in order to check their voice messages, send or receive text messages, take a picture, play a game, or access the Internet. Organizing schedules, setting reminders for appointments, and calculating numbers are just a few functions that a mobile device is capable of doing. Some versions of cell phones function like miniature computers. While these handy gadgets do have many positive aspects, they have some very serious negative side affects. First, the implications of using a cell phone while driving will be discussed, followed by the controversial issue of cell phones emitting harmful electromagnetic fields and radio frequencies which (some researchers are starting to fear) cause brain tumors in the heads of regular cell phone users.

There are numerous accidents that occur every day around the world because someone is using their cellular device and not paying attention to what they are doing. These accidents range from bumps and bruises due to text messaging (texting) while walking, to fatalities caused by a driver talking or texting on their cell phone while on the road. Many victims of texting while walking now have other methods to prevent getting hurt again. Searcey [21] interviewed some texters and found that they often put their arm out in front of them while walking so they do not run into anything. Also, they keep their heads at a different angle so they can see where they are going, as well as what they are texting. "In London, directory-services company 118 118, operated by The Number UK Ltd., began a publicity campaign in March of 2008, outfitting lampposts with padded bumpers in the East End to cut down on injuries to errant texters". [21] Many texters have memorized their keypads, which makes texting faster, but not much safer when it comes to driving. Research shows that driver inattention is the leading factor in most crashes and near-crashes [8]. Not surprisingly, the cell phone is among the leading contributors of driver distraction. Some drivers take on the task of eating on the go, applying makeup, or reading a book, but most all drivers, at some point in time have used their cell phones while driving. Although it seems that most of the hype about cell phone related accidents is focused on talking while driving, texting is becoming very popular, especially with the teenager to young adult population.

Texting is worse than talking on the phone and driving, because drivers have to take their eyes off of the road. Richards discovered a study by the Transport Research Laboratory which found that the 
"reaction time of people driving while textmessaging was 35 percent slower, while reaction times were down 12 percent for drunk drivers and 21 percent for marijuana smokers" [19]. It is pretty frightening to imagine that a cell phone can make a driver more dangerous than drinking alcohol. To keep up with the texting craze, cell phone companies are producing more phones with keyboards similar to those on computers, but scaled down to size. This obviously will give more users an incentive to text while driving because the keyboards are easier to use. Teenagers are certainly taking advantage of the latest technology trends. "Nearly 40 percent of drivers between the text-crazed ages of 18 and 27 send text messages while behind the wheel, compared to 19 percent for all drivers, according to a 2006 study by Nationwide Insurance" [22]. Texting is useful in certain situations, but not while behind the wheel of a moving vehicle.

Talking or texting on a cell phone while driving is essentially connected to motor vehicles, but a train wreck in California informed the entire country that all moving vehicles are subject to cell phone dangers. On September 12, 2008 the engineer of a Metrolink commuter train, Robert M. Sanchez, was texting while operating the train only minutes before it collided with a Union Pacific freight train. McKinley and Wald [12] confirmed that he ran a red light northwest of downtown Los Angeles. Twenty-five people were killed and more than 130 injured. Mr. Sanchez, who did not brake before the collision, was killed in the crash. The California Public Utilities Commission quickly passed an emergency order banning the use of cell phones and similar electronic devices by engineers operating trains [10]. In light of this accident, California governor, Arnold Schwarzenegger issued a ban that went into effect January 1, 2009. Drivers will no longer be able to read, write, or send text messages while behind the wheel of a moving vehicle. If drivers are caught texting there will be a $\$ 20$ fine for the first offense and a $\$ 50$ fine for any subsequent violation [24]. Already, drivers in California over the age of 18 cannot hold a cell phone and talk while driving. However, they are allowed to use earpieces.

There are certain organizations that will help individuals obtain earpieces. For instance, FreeHeadset.org allows customers to select their make and model of phone, which then gives a list of available headsets. The client picks the headset they desire and orders it. They only have to pay shipping on the product. This particular organization is trying to promote safer driving. Since December 2003, they have been running a worldwide wireless phone safety program that distributes free cell phone headsets to individuals. They have given out over 260,000 headsets [7]. Many people choose to take advantage of this opportunity, but in reality a headset doesn't make conversing on the phone while driving any safer.

New cell phone laws may be counterproductive; instilling a false sense of security, since they may lull drivers into thinking that gabbing on the hands-free phone is safe. Drivers think that because their hands will be on the wheel, they'll be a safe driver, but a hands-free phone isn't much safer than a hand-held when you're behind the wheel [14]. The root of the cell phone problem is the conversation: a person's brain cannot distinguish between a hand-held or hands-free phone. In a recent study, Maples et al. [11] discovered that two possible sources of driver distraction exist for cell phone use. The first is the physical aspect of holding the phone and dialing numbers. The second is the cognitive drain on the driver's attentive resources to process the conversation. Even though a person talking on a cell phone may try to tune out the person speaking on the other end of the line, their brain will not allow it [14]. When one finds themselves in a bad position while driving, they cannot ignore the conversation, so their driving suffers. Also, as a phone user listens intently to the caller, "the part of the brain that focuses on visual tasks begins to shut down. That is one reason you often see cell phone drivers speeding up, slowing down, cruising in the fast lane at $50 \mathrm{mph}$ or blowing through a stop sign" [19]. There are more people using cell phones today, so the number of vehicles on the road with a talking driver behind the wheel is increasing.

Many advocates of talking while driving compare the cellular conversation to that of a driver/passenger conversation. They believe that if a driver is not allowed to talk on the phone while driving, they should not be able to talk at all. Although these two instances seem to have similarities, they are very different. The driver does have to allocate part of their thinking to the conversation with the passenger, but the passenger knows when to stop talking when the driving situation gets rough, and the person on the other end of the cell phone conversation does not. Mieszkowski discovered: Inside a car, there can be natural lulls in the conversation of 20 or 30 seconds, and there is no awkwardness associated with it. Not so on the cell phone call, where there's more social pressure on the driver to hold up his or her end of the conversation, if only to assure the other party that the 
call hasn't been dropped. When a driver does stop talking to focus on the road, his caller is likely to ask, "Hey, can you hear me? Are you there?" (p. 3) [14] Also, passengers in the car have their own safety to think about, so they don't want to engage the driver in conversation at the wrong time.

The Accident Analysis and Prevention group performed a study comparing hands-free, hand-held, and speaker phones. Ferlazzo, Fagioli, Nocera, and Sdoia [5] determined: People process auditory information more efficiently when relevant auditory and visual stimuli are presented from the same spatial locations. The shift of spatial attention between near and far positions is one of the mechanisms that determine the dual performance cost of driving while conversing, and that affects differently the cost of conversing through hand-held- and earphone- versus loudspeaker-operated phones.[5] They found that there was really no difference in using a hands-free versus a hand-held phone. The participants in the study reacted about the same amount of time to visual stimulations presented to them while driving with a hand-free and a hand-held cell phone. Speaker phones, on the other hand, proved to be beneficial to the driver. Driver reaction times were significantly less, which showed that a speaker phone enables drivers to pay more attention to their driving.

It has been demonstrated that it is more difficult to disengage attention from spatial locations within the personal space, and to engage it on farther spatial locations than the other way around. This is especially interesting because this condition occurs when drivers are engaged in a conversation through hand-held and earphone-operated hands-free phones. Drivers have to shift continuously their attention from the near, personal space wherein the conversation takes place to the peri-personal and extra-personal spaces (e.g. the dashboard, the road) where most of the driving related information are deployed. Instead, such shifting of attention between the personal and the farther spaces does not occur when drivers use loudspeaker-operated phones or talk with passengers [5].

To help reduce the amount of accidents occurring in the United States, many individual states have taken it upon themselves to pass laws preventing drivers from using their cell phones while driving. The GHSA [8] compiled a list showing: There are six states [California, Connecticut, New Jersey, New York, Oregon and Washington], the District of Columbia and the Virgin Islands that have enacted cell phone laws prohibiting driving while talking on a handheld cell phone. With the exception of Washington State, these laws are all primary enforcement - an officer may ticket a driver for using a handheld cell phone while driving without any other traffic offense taking place. Alaska, Arkansas, California, Colorado, Connecticut, the District of Columbia, Illinois, Louisiana, Maryland, Minnesota, New Hampshire, New Jersey, New York, North Carolina, Oregon, Tennessee, Utah, Virginia and Washington already have text messaging bans for all drivers. No state completely bans all types of cell phone use for all drivers. [8] In the states with laws implemented, the amount of cell phone related accidents are steadily decreasing.

Jed Kolko, an economist with the Public Policy Institute of California, studied the fatality rates in New Jersey, New York, Connecticut, and D.C. before and after their hand-held cellphone bans went into effect, also comparing traffic fatalities with those in states that id not implement bans. Based on his data, Kolko predicts that California will see 300 fewer traffic fatalities per year [14].

Texas has primary enforcement concerning school bus drivers with passengers under or at the age of seventeen, and for drivers under the age of eighteen. Most states have laws against minors using electronic devices while driving.

The GHSA [8] determined that the leading causes of death for 15-20 year olds are vehicle crashes. Vehicle crashes make up approximately one-third of all deaths for this age group. These statistics are caused by a teenager's immaturity, driving inexperience, overconfidence, and risk-taking behaviors. Most teenagers think it looks cool to do daring stunts on the road once they receive their license, but they do endanger other drivers' and pedestrians' lives. The common saying, "Watch out for (name of a person), he/she just got their driver's license," sadly is a true statement. Most teen drivers have all of the latest technological gadgets that they feel have to be constantly utilized. Young drivers appear more willing to accept new technologies and devices. As they gain more confidence, they tend to over-estimate their ability to multitask with in-vehicle devices while driving [16]. "The wireless trade association CTIA and Harris Interactive surveyed some 2,000 teens across the country and learned that teens feel cell phones are a vital part of their identities. They also believe that they can gauge a peer's popularity or status by the phone he or she uses"[3].

Even though several states have taken a stand against allowing drivers to use a cell phone while driving, the 
insurance industry has not taken a position on the bans. Of the states banning handheld cell phone use among all adult drivers, only Utah assesses points against a license. A driver who accumulates a certain number of points may have to take driving lessons, pay fines or surrender his or her license [20]. If drivers would suffer consequences, like having an increased insurance premium, they may pay attention to the laws. Like most individuals, the occupants of this particular state probably do the lawful thing in front of law enforcement officers, but begin their bad habits once they are out of sight. Drivers need to be more considerate of other people, because their lives are not the only ones at risk when they text or talk behind the wheel.

Once again, the question is will cell phone bans work? As insurers and other key stakeholders put forth efforts to thwart the ill effects of driving while distracted (DWD), a key question is whether laws or technology will succeed in changing patterns of driver cell phone use. [9]

With an astounding 110.4 billion text messages sent and received each month in 2008 , it is obvious that texting is easy, fast, and increasingly popular. It is also quite incompatible with and sort of safe driving. So what are the long term effects of laws banning cell phone use over time? Researchers have been observing phone use multiple times from 2001 to 2009 in both the study states and nearby communities without phone bans. The purpose was to estimate the proportion of drivers expected to be using hand-held phones if the laws had not been enacted.

Hand-held phone use was an estimated 65\% lower in Connecticut, 24\% lover in New York and 43\% lower in the District of Columbia than would have been expected without the laws. [9]

Laws banning cell phone use while driving may be difficult to enforce. The crash risk is about the same, whether drivers use hand-held or hands-free phones, so if motorists respond to hand-held bans by switching the type of phone they use, they may not be reducing crash risk. However, hands-free phones are much harder to enforce. [9]

A recent survey of National Safety Council members has revealed that 99 percent of companies with policies prohibiting the use of cell phones and messaging devices while driving have experienced no change in productivity, and some have even seen an increase in productivity. Productivity concerns have been touted as a top reason for not establishing a cell phone policy in the past. [18] It appears that many businesses are starting to shift their position concerning cell phone use by their employees while driving.

\section{CELL PHONE USA AND PERCEIVED MEDICAL RISKS}

Together with the substantiated dangers of talking and texting while driving, are the supposed risks associated with cell phones emitting radio frequencies that might cause brain tumors from heavy or long term use. This is an extremely controversial issue in the science and medical fields. Many science and medical professionals have performed studies to try and prove the association between cancer and cell phones, but none have conclusively made the connection. It is believed that the "controversy over cell phones and cancer started on national television in 1993, when Larry King interviewed a man who said that his wife's fatal brain tumor had been caused by her cell phone" [25]. The tumor was supposedly in the shape of a cell phone antenna, so the husband put two and two together. However, many professionals believe that there is a pattern emerging that suggests people who have used their cell phones for a long period of time are at greater risk of certain kinds of brain tumors [13]. Some studies have shown increased cancer risks in individuals who use their cellular devices often, but no study is $100 \%$ accurate because cell phones have never been used at the rate that they are today. Cell phone plans started with a minimum amount of minutes for individuals to utilize, but people continually went over these limits, causing large fees to appear on their bills. Now, many plans allow cell phone users to have unlimited minutes. The downside of having better plans is that "talking 500 minutes per month on a cell phone increases the probability of brain cancer by $140 \%$. Some studies show up to 300 percent increase when using the cell phone between 500 and 1,000 minutes per month" [6].

Researchers suggest that we might be on the brink of a brain cancer epidemic. Mercola [13] predicts that there might be half a million brain tumor victims in the next few years, and possibly over a million in the U.S. alone by 2015. Currently, there are more and more findings of brain and eye cancer each year attributed to cell phone use; these numbers reach well over 10,000 cases [13]. These results are not well known because cell phone companies want to keep this information under wraps for fear it will scare cell phone customers. The University of Pittsburgh 
Cancer Institute [23] defined cancer as a complex disease that occurs when cells lose their ability to stay in order. According to the National Library of Medicine (2008):

The only known causes for brain tumors or cancers are: 1 . Previous radiation therapy to the head area. 2 . Exposure to some chemicals. These chemicals are formaldehyde used by pathologists and embalmers. Vinyl chloride used in the manufacturing of plastics and acrylonitrile used in the manufacturing of textile and plastics. [15]
If you notice, cell phones are not among this list, however it has been found that "cell phone radiation has the capacity to disturb normal cells and the cell phone industries own studies show that the cell signal is absorbed deeply into the brains of children, and up to 2 inches into an adult skull" [23]. The figure below shows the different cranial degrees of electromagnetic field penetration between a five and ten year old child and an adult.

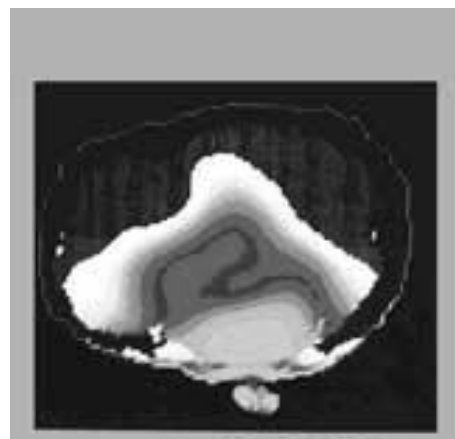

5 yr old child

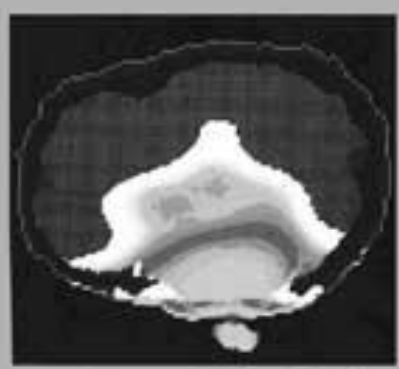

$10 \mathrm{yr}$ old child


Adult
According to the figure retrieved from the University of Pittsburgh Cancer Institute [23], the harmful emissions are almost thoroughly absorbed into the five and ten year old child's brain, but only a couple of inches into the adult skull. Children's and infant's bones are still developing, so their skulls are much more penetrable compared to an adult. Many scientists and medical professionals warn parents not to allow their children to talk on a cell phone under any circumstance. Unfortunately, nearly half of kids age 8 to 12 years old own cell phones in the U.S, and on average kids get their first cell phone between the ages of 10 and 11 years old [3]. Ferris (2008) states that, "Children's brains are penetrated $75 \%$ more by cell phone radiation. Just 2 minutes on a cell phone can negatively impact a child's bio-field for more than an hour later" [6].

Mercola (2008) found that the dangers emitted from cellular devices come from two sources: "the modulated signals that are carried on the carrier microwave, and the carrier wave itself" (p.3). Mercola (2008) also discovered that these waves cause vibrations in your brain creating: A whole cascade of pathological consequences that can culminate in fatigue, anxiety, and ultimately cancer. Your cells will interpret even a minute amount of cell phone radiation as a threat, and will shut down many vital processes. This is a response intended to protect them, but when you talk on a cell phone, it lasts for far longer than your body can handle. [13]

The longer a person talks on their phone, the more apt they are to have tumors later in life. This is the reason that most young children and teenagers will be the ones affected by the cell phone tumor epidemic because they will have used these devices for the majority of their lifetimes. The reason for the cautioning parents not to let their children have a cell phone abound. [13]

A misconception that most people make is that cell phones can only harm the brain if the phone is held to the head while talking. Cellular devices constantly emit radiation when they are on. Thus, anywhere you keep your phone you will be receiving radiation, just in different doses. It is suggested that if you carry your phone with you, keep it in a purse or other location away from your body. Some believe that the radiation emitted from the cellular device can roast 
your bone marrow. To prevent this from happening, it is preferable that the keypad is positioned toward your body and the back be positioned toward the outside of your body [23]. When at home, leave your phone in a particular location (preferably away from where you are) and only use it when answering or making a phone call. Also, you should not put the phone up to your ear until you know that the person you are calling has answered. This helps limit the time you're exposed.

There are numerous reasons for using a cell phone, but now those reasons seem insignificant compared to the possibility of having brain tumors. For instance, many people use their cell phones as alarms because they have it whenever they travel. They already know how to use their cell phones so they don't bother learning how to use the alarm in the hotel or motel room. You should avoid keeping your phone near your body at night (like under a pillow or on a bedside table) [23]. If users of cell phones heed these warnings, even though there is no medical proof of brain tumors, they could greatly improve their chances of not contracting a tumor if the rumors turn out to be true. Many nations, including the United States, are starting to warn people of the looming danger of cellular devices. The University of Pittsburgh Cancer Institute [23] found: The governments of other nations, including France, India, Canada, and Israel have all issued warnings about the dangers of electromagnetic fields emitted from cell phones. In the U.S., the Federal Drug Administration has recommended placing more distance between your body and your phone or using a headset to reduce your exposure to electromagnetic radiation. [23]

According to a news release in the New York Post, a groundbreaking, $\$ 30$ million study into cell phones has found a link between long term cell phone use and brain tumors. [17] The World Health Organization is about to reveal that as decade-long investigation has found the devices can lead to cancer, and the internationally respected body will soon issue a public health message with its findings. These conclusions go against years of assurances by cell phone companies and scientists that cell phone use is safe. [17]

Many cell phone users have opted to talk on headsets because they are thought to be safer when driving, but as discussed previously, studies suggest this is false. Now, the headsets may be protecting users from the radiation emitted from cell phones, but they are not protecting you from distractions. And not all headsets are thought to be safe. If a wired headset is not well-shielded - and most of them are not - the wire itself acts as an antenna attracting ambient information carrying radio waves and transmitting radiation directly to your brain. Most cell phones have the ability to be used through a speaker; this helps eliminate the user's exposure to the radio waves. Mercola (2008) discovered that the most dangerous place to be, in terms of radiation exposure, is within about two feet of your device's antenna. If you are able to use your phone through a speaker, be sure to keep it at least two feet away from your body. For times when a speakerphone is not practical, use an air-tube headset, rather than a wireless Bluetooth headset because the Bluetooth set emits small amounts of radio waves [13].

Some entrepreneurs are cashing in on the brain tumor scare. Whether these products are legitimate or not is a matter of opinion, but there are products such as ferrite beads, which clip onto the wire of your headset. The wire is what transmits the radiation to the cell phone user and the bead supposedly absorbs the radiation [4]. This product assumes that you already use a headset instead of just a handheld. Another company called BIOPRO Technology sells a Cell Chip that attaches directly onto a mobile device.

BIOPRO's Cell Chip combines the benefits of two powerful, innovative and scientifically substantiated technologies: the proprietary, patented noise field nanotechnology MRET ${ }^{\circledR}$ (Molecular Resonance Effect Technology), and the proprietary subtle energy innovation ERT ${ }^{\mathrm{TM}}$ (Energy Resonance Technology). Individually and collectively, these cutting-edge technologies offer a groundbreaking and effective way to deal with the cumulative stress associated with living in today's electronic environment [1].

Undoubtedly, many of these products have been sold to consumers trying to prevent their brains from turning into fried eggs. Hopefully they are getting their money's worth out of these innovations.

The world has steadily integrated wireless communications into everyday life. The cell phone, smart phone, and other gadgets are so handy and they make life so convenient that it is difficult to imagine life without them; dangerous or not. There has been no conclusive scientific or medical evidence to prove that there is a connection between cell phones and cancer, but is the world going to take a "wait and see" attitude, or is it going to take action before its worst nightmares become a reality? People are living to the ages of 80,90 , and beyond due to the advancement of medicine. It would be a ironic if the cell phone, intended to move society forward, caused mass illness and misery instead. A grim picture is painted if you imagine humans not living past the 
ages of 30 and 40 . Whether the brain tumor epidemic will eventually turn out to be just a hoax, somewhat like the year $2 \mathrm{~K}$ scare, is still to be determined. Let us hope this does not become a technological asbestos crisis.

\section{CONCLUSIONS}

The only proven and apparent dangers of cell phones are that they cause driver distractions which can often lead to the death of the driver, passengers, or pedestrians. Regardless of the laws being put into place to help prevent these accidents from occurring, many cell phone users will continue to push their limits until a possible tragedy occurs. Often times, it takes a personal incident to cause someone to realize that a behavior is dangerous.

It may take decades for public concern about this problem to catch up with the ubiquity of cell phone use behind the wheel. The first drunken-driving law went into the books in 1917, yet it wasn't until the 1980s that a grass-roots movement, spearheaded by the likes of Mothers Against Drunk Driving and Students Against Driving Drunk, led to wide enforcement and tougher laws. It will likely take a similar national mobilization of the aggrieved family members of people killed or maimed by drivers talking on cell phones to raise public awareness of just how dangerous it is [14]. Until people decide to take the laws seriously, there will be continued reports of cell phone related accidents.

The next time you decide to pick up your cell phone to make/answer a call, or send/read a text message remember that there are other people that might possibly be harmed if you are not paying attention while driving. If you often find yourself in an emergency situation where you cannot wait to use your cellular device, invest in a loudspeaker system for your vehicle to improve your chances of not having a fatal accident. Also, until there is factual proof showing that cell phones do not cause brain tumors, take the necessary precautions to protect yourself. Use your speakerphone whenever possible and hold the phone at least two feet away from your body, purchase an earpiece (preferably an air-tube), or invest in one of the latest technologies that absorbs most harmful cellular emissions. The world is still dealing with the unknown, but are we flirting with the lesser of two evils? Either way, the handy little gadgets that have become a vital part of life may very well cause, for some, the ending of that life.

\section{REFERENCES}

1. BIOPRO Technology. (2008). Biopro cell chip. Retrieved February 10, 2010, from http://www.bioprotechnology.com/BIOPRO _Template.aspx?ItemID $=1450$

2. California Department of Motor Vehicles. (2008, July). Driver distractions - Don't be a statistic. Retrieved February 12, 2010, from

http://www.dmv.ca.gov/pubs/brochures/fast _facts/ffd128.htm

3. CNET. (2008, September 15). Survey: Teens' cell phones indispensible. CBS News. Retrieved February 27, 2010, from http://www.cbsnews.com/stories/2008/09/15 /tech/cnettechnews/main4449232.shtml?sou rce=search_story

4. Cohen, E. (2008, July 31). 5 tips to limit your cell phone risk. Retrieved February 28, 2010, from http://www.cnn.com/2008/HEALTH/07/31/ ep.cell.phones.cancer/index.html

5. Ferlazzo, F., Fagioli, S., Nocera., \& Sdoia, S. (2008). Shifting attention across near and far spaces: Implications for the use of handsfree cell phones while driving [Electronic Version]. Accident Analysis and Prevention (in press).

6. Ferris, G. F. (2008, September 6). Silent killer. Retrieved February 26, 2010, from http://onlinemoneyaffiliate.com/article/2min celluse.pdf

7. FreeHeadset.org. (2008). Retrieved February 21, 2010, from http://www.freeheadset.org/home.php

8. Governor's Highway Safety Association [GHSA]. (2008, July). Cell phone driving laws. Retrieved March 9, 2010, from http://www.ghsa.org/html/stateinfo/laws/cell phone_laws.html

9. Insurance Headlines. (2009). Will Cell Phone Bans Work? Retrieved March 9, 2010, from http://www.insuranceheadlines.com/AutoIns urance/6266.html 
10. Levin, A. (2008, September 19). Train operators' cellphone use eyed. USA Today, p. 3A.

11. Maples, W. C., DeRosier, W., Hoenes, R., Bendure, R., \& Moore, S. (2008). The effects of cell phone use on peripheral vision [Electronic Version]. Optometry, 79, 36-42.

12. McKinley, J., \& Wald, M. (2008, September 19). California bans texting by operators of trains. The New York Times. Retrieved March 2, 2010, from http://www.nytimes.com/2008/09/19/us/19cr ash.html

13. Mercola, J. (2008, August 9). Why children and teens should stay away from cell phones. Retrieved March 8, 2010, from http://articles.mercola.com/sites/articles/arch ive/2008/08/09/why-children-and-teensshould-stay-away-from-cellphones.aspx? source $=\mathrm{n} 1$

14. Mieszkowski, K. (2008, July 25). Hang up and drive. Retrieved March 6, 2010, from http://www.salon.com/news/feature/2008/07 /25/cell_phone_driving/pring.html

15. National Library of Medicine. (2008). XPlain brain tumors. Retrieved February 14, 2010, from http://www.hlm.nih.gov/medlineplus/tutorial s/braincancer/oc119103.pdf

16. Neyens, D., \& Boyle, L. (2008). The influence of driver distraction on the severity of injuries sustained by teenage drivers and their passengers [Electronic Version]. Accident Analysis and Prevention, 40, 254-259.

17. Nichols, Adam (2009, October 24). Study:Cell phone cancer link. The New York Post. Retrieved March 2, 2010 from http://www.nypost.com/p/news/national/stud y_cell_phone_cancer_link_D1uu62C2zscTF CnzQTeZwo.html

18. PR Newswire. (2009, October 23). Number of Companies Implementing Cell Phone Bans Grows. Retrieved February 13, 2010, from http://www.prnewswire.com/newsreleases/number-of-companiesimplementing-cell-phone-bans-grows65807477.html
19. Richards, G. (2008, September 19). Roadshow: Next likely law: No textmessaging behind the wheel. The Mercury News. Retrieved February 25, 2010, from http://www.mercurynews.com/mrroadshow/ ci_10510656?nclick_check=1

20. Roe, A. (2008, August 15). Will drivers ignore new phone bans? Retrieved March 7 , 2010, from http://www.articles/moneycentral.msn.com/I nsurance/InsureYourCar/DriversIgnoringCel lPhoneBans.aspx

21. Searcey. D. (2008, July 25). Generation text: Emailing on the go sends some users into harm's way. The Wall Street Journal. Retrieved March 8, 2010, from http://online.wsj.com/article/SB1216948602 00483347.html

22. Spielman, F. (2008, October 2). City expected to ban driving while texting. Chicago Sun-Times. Retrieved March 12, 2010, from http://www.suntimes.com/news/politics/119 5669,text100108.article

23. University of Pittsburgh Cancer Institute. (2008). Questions and answers on electromagnetic fields and our health. Retrieved January 12, 2010, from http://www.environmentaloncology.org/files /file/Publications/CellPhoneFAQ.pdf

24. Vogel, N., \& Rothfield, M. (2008, September 25). Schwarzeneggar outlaws text-messaging while driving. Lost Angeles Times. Retrieved February 1, 2010, from http://www.latimes.com/news/local/la-mearnold25-

2008sep25,0,6433956.story?track=rss

25. Winstead, E.R. (2008). Cell phones and brain cancer: What we know (and don't know). NCI Cancer Bulletin, 5(19), 7-8. Retrieved January 31, 2010, from http://www.cancer.gov/NCICancerBulletin/ NCI_Cancer_Bulletin_092308.pdf 